\author{
O.N. BONDAREV
}

\title{
MINIMALLY INVASIVE OSTEOSYNTHESIS OF FRACTURES OF THE TIBIAL CONDYLES
}

\author{
SE "Republican Scientific and Practical Center for Traumatology and Orthopedics”, Minsk, \\ The Republic of Belarus
}

Цель. Провести сравнительный анализ результатов малоинвазивного и традиционного открытого остеосинтеза у пациентов с переломами мыщелков большеберцовой кости.

Материал и методы. В зависимости от проводимого метода хирургического лечения переломов мыщелков большеберцовой кости пациенты были разделены на две группы. В первой группе $(\mathrm{n}=70)$ применялась открытая репозиция перелома с внутренней фиксацией. Во второй группе $(\mathrm{n}=70)$ применены малоинвазивные методы лечения: закрытая репозиция и чрескожная фиксация канюлированными винтами, репозиция через трепанационное окно с фиксацией винтами/пластиной, малоинвазивный остеосинтез пластинами, артроскопически ассистированный остеосинтез. В сравниваемых группах оценивали следующие показатели: длительность операции, рентгенологический результат лечения, функциональное состояние нижней конечности, длительность временной нетрудоспособности.

Результаты. Установлено, что применение малоинвазивных хирургических методов лечения переломов мыщелков большеберцовой кости позволяет сократить длительность операции с 100 (90-120) до 70 (60-90) минут (Ме (25\%-75\%)), однако не влияет на качество репозиции и количество инфекционных осложнений. Также отмечено, что использование малоинвазивных методов остеосинтеза переломов мыщелков большеберцовой кости позволяет сократить время временной нетрудоспособности с 24 (22-41) недель до 21 (17-33,5) (Ме (25\%-75\%)) и достичь лучших функциональных результатов по сравнению с традиционными открытыми методами лечения. Изучение отдаленных рентгенологических результатов лечения показало, что оба метода лечения позволяют достичь удовлетворительной репозиции костных фрагментов. При переломах типа Schatzker 1 и 2 выявлены преимущества малоинвазивных методов лечения. Качество репозиции переломов типа Schatzker 3-6 в обеих группах сопоставимо. Следует отметить, что независимо от примененного метода лечения репозиция бикондилярных переломов (Schatzker 5, 6) сопровождалась худшим рентгенологическим результатом по сравнению с результатами одномыщелковых повреждений.

Заключение. Проведенное исследование подтвердило эффективность применения малоинвазивных хирургических методов в лечении пациентов с переломами мыщелков голени.

Ключевые слова: переломы мыщелков большеберцовой кости, малоинвазивный остеосинтез, тибиальное плато

Objectives. To carry out a comparative analysis of the results of minimally invasive and traditional open osteosynthesis in patients with fractures of the tibial condyles.

Methods. The patients were divided into two groups depending on the performed surgical treatment method of the fractures of the tibial condyles. In the first group $(n=70)$ the open reposition of the fracture with the internal fixation was applied. In the second group $(n=70)$ minimally invasive treatment methods were used: the closed reposition and percutaneous fixation with cannulated screws, reposition through the trepanation window with screws/plate fixation, minimally invasive osteosynthesis by plates, arthroscopically-assisted osteosynthesis. The following parameters were evaluated in the compared groups: the duration of the operation, the radiographic result of the treatment, the functional condition of the lower limb and the duration of temporary work incapacity.

Results. It has been found out that use of minimally invasive surgical treatment of fractures of the tibial condyles reduces the operative time from 100 (90-120) to 70 (60-90) minutes, but does not affect the quality of the reposition, and the number of infectious complications. It is also noted that the use of minimally invasive osteosynthesis of fractures of the tibial condyles permits to reduce the time of temporary disability from 24 (22-41) weeks to $21(17-33,5)$ and achieve better functional outcomes compared with traditional open procedures. The study of long-term radiographic results of treatment showed that both methods of treatment permit to achieve a satisfactory reposition of bone fragments. In Schatzker type I and II fracture the advantages of minimally invasive treatment methods have been determined. The quality of reposition of Schatzker type III and VI fracture in both groups is comparable. It should be pointed out that regardless of the treatment technique used, reposition of the bicondylar fractures (Schatzker type V and VI) was accompanied by worse radiological outcomes in comparison with the results of single condyle damage.

Conclusion. The performed research has proved the efficacy of minimally invasive surgical procedures for the treatment of patients with tibial condylar fractures.

Keywords: tibial condylar fractures, minimally invasive osteosynthesis, tibial plateau, radiological outcome, complications, reposition 
Novosti Khirurgii. 2017 May-Jun; Vol 25 (3): 279-285

Minimally Invasive Osteosynthesis of Fractures of the Tibial Condyles

O.N. Bondarev

\section{Introduction}

Treatment of patients with intraarticular fractures of the tibia condyles is an actual problem of current traumatology. This is due to the incidence of damage i.e. proximal femoral fractures make up about $10 \%$ of all shin fractures [1], as well as there is a high proportion of unsatisfactory outcomes of treatment such as posttraumatic arthrosis, axial deviations, limitations of joint mobility and infectious complications.

Difficulties in treating the damage of this localization are associated with their intraarticular properties and require the use of current diagnostic methods (CT, MRI), as well as with a high frequency of severe damage to soft tissue skins in these fractures [2,3]. The soft tissues of the shin proximal portion are small thickness, that explains the high incidence of wound complications in the surgical treatment of such fractures. The use of conventional open reposition and internal fixation by the plates requires a significant denudation of the bone while isolating the fragments. The use of expanded accesses for bicondylar damages is accompanied by wound complications in $45-55 \%$ of cases [4], that demands two surgical approaches to fix such damages: anterolateral for reposition and fixation of the external condyle, and posteromedial for fixation of the opposite side of the joint (of the internal condyle). Nevertheless, the frequency of infectious complications continues to be high (from 1\% to 38\%), and depending on the surgical technique used, the timing of the intervention and the state of soft tissues.

Identation of the bone tissue with occurrence of considerable defects determines the necessity of using bone plasty approximately in $40-60 \%$ of patients [5].

One of the promising directions in the treatment of the proximal tibia fractures currently use the minimally invasive surgical methods of repositioning and osteosynthesis allowing the maximum preservation of the bone fragment and the soft tissue, thereby ensuring their blood supply. However, the available scientific sources do not adequately illustrate the long-term results of minimally invasive methods of surgical treatment of tibial condyle fractures in comparison with the results of conven- tional open osteosynthesis. That was the basis for the present study.

Objectives. To carry out a comparative analysis of the results of minimally invasive and conventional open osteosynthesis in patients with fractures of the tibia condyles.

\section{Methods}

In the period from 2007 to 2015,140 patients (73 men and 67 women) with the fractures of the tibial plateau were being treated at the trauma and orthopedic department for adults of the Republican Scientific and Practical Center of Traumatology and Orthopedics (RSPTC). In the patients of the first group $(n=70)$ minimally invasive methods of repositioning and fixing fractures were used. The term "minimally invasive methods" means:

A. The closed reposition and percutaneous fixation by the cannulated screws -8 patients;

B. The reposition through the trepanation window with the fixation by screws/plate -12 patients;

C. Minimally invasive plate osteosynthesis 35 patients;

D. Arthroscopically-assisted osteosynthesis 15 patients.

In the control group of patients $(n=70)$, conventional open methods of osteosynthesis were used.

The long-term results of treatment were studied in all patients (9-44 months; on the average 17,2). The average age of the patients was 51 (38-61) years Me (25\%-75\%). According to J. Schatzker's classification [6], the distribution of patients is as follows (Table 1):

According to the force there are a high-energy trauma, noted in $35,2 \%$ of cases -25 patients $(9-$ a fall from the height, 16 - accidents) and a lowenergy trauma - in $64,8 \%$ (46 patients). The period prior to the operation was from 1 day to 1,5 months (on the average 7,6 days).

A. The closed reposition and percutaneous screw fixation $(n=8)$ was performed in patients with good quality of the spongy bone with the Schatzker type I fracture -6 cases and type IV -2 cases (Figure 1).

After the closed reposition the fixing of the fracture by 2-3 cannulated screws was carried out along the guide spokes under the control of an opticalto-electrical converter $(\mathrm{O} / \mathrm{E})$. After osteosynthesis,

Distribution of patients with the fractures of the tibial condyles

\begin{tabular}{|c|c|c|c|c|c|c|c|}
\hline & Schatzker 1 & Schatzker 2 & Schatzker 3 & Schatzker 4 & Schatzker 5 & Schatzker 6 & total \\
\hline $\begin{array}{c}\text { Number } \\
\text { of patients }\end{array}$ & 7 & 20 & 12 & 8 & $\overline{7}$ & 16 & 70 \\
\hline
\end{tabular}




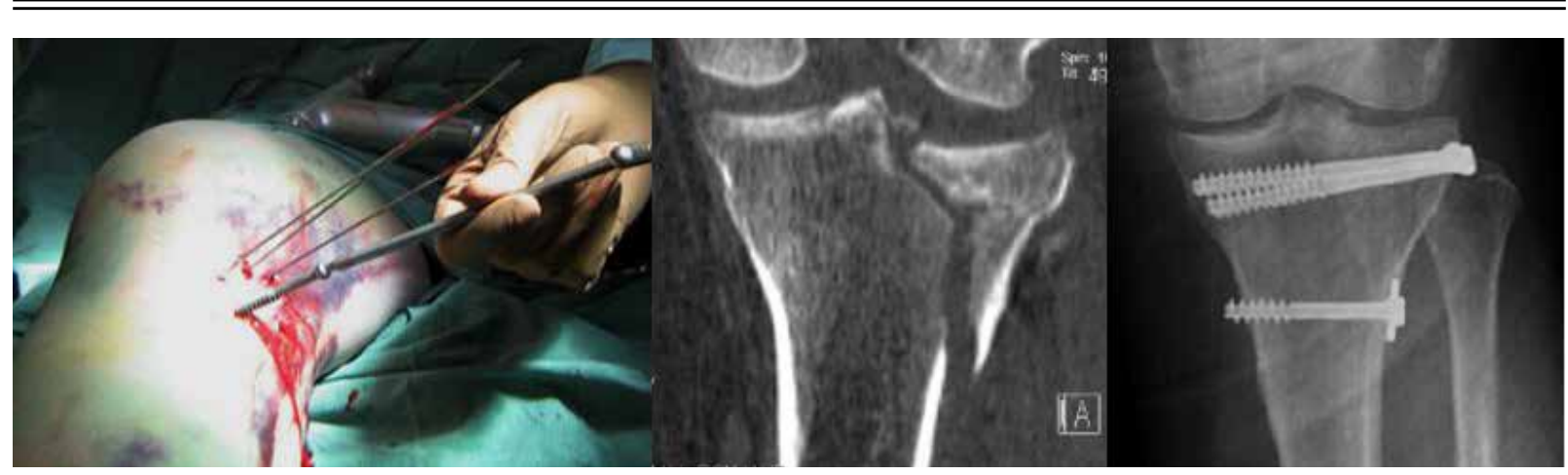

Fig. 1. The closed reposition and percutaneous fixation

the ligamentous stability of the knee joint was tested (an obligatory stage for any kind of osteosynthesis).

B. Reposition through the trepanation window under fluoroscopic control $(n=12)$. This surgical procedure was performed in patients with the Schatzker 2,3 type fractures. The fracture was repositioned under the $\mathrm{O} / \mathrm{E}$ control. The indented bone fragments required the anatomical reposition. To do this, the bone fragments were repositioned according to the original technique with the restoration of the articular surface (patent No. 18055) [7].

From an approach (the length up to 3-4 cm), located $2 \mathrm{~cm}$ medially to the tibia bone tuberosity, the portion of the medial surface of the tibia was opened in the metaphyseal region.

Under the fluoroscopic control, the guide wire was passed through the cortical layer along the inner surface of the tibia in the fracture zone of the external condyle.

Further, a hollow cutter (optimally $12 \mathrm{~mm}$ ) formed the channel in the tibia. The obtained free portion of the cortical layer was implanted into the tibial canal and it was located parallel horizontallyoriented to the articular fissure directly beneath the repaired osseous fragments (Fig. 2).

To fix the bone fragments the cannulated compression screws were inserted beneath the implant, or plates to the proximal segment with appropriately oriented screws were used. To prevent the impression recurrence in case of the fractures with a significant defect in bone mass, the bone plasty was performed with a bicortical bone graft from the isolateral ridge of the ilium wing after the reposition of the joint surface (4 cases $-33 \%$ ).

C. Minimally invasive plate osteosynthesis $(n=35)$ was used in one patient with Schatzker 1 type fracture, in 9 patients - with Schatzker 2 type fracture, in 1 - with Schatzker 3 type fracture, in 3 with Schatzker 4 type fracture, in 7 - with Schatzker 5 type fracture, and in 15 patients - with Schatzker 6 type fracture.

Before using this type of osteosynthesis, displacement of the fragments was corrected along the length with the restoration of the limb axis. The manual reposition was used in 29 cases and the rod distractors - in 6 .

Bicondylar fractures of Schatzker 5 and 6 types were considered to be the most severe damages with an unfavorable prognosis for recovery.

All patients with this type of fractures required the postponement of surgical interventions for 7-10 days due to the vascular disturbances associated with fractures (edema, abrasions, (phlyctaena). Only after normalization of soft tissues the surgeons were able to perform osteosynthesis.

In 16 cases, after the closed reduction of the fracture manually, a satisfactory position of the fracture of the inner condyle was achieved. In these patients, the use of plates with locking of screws, providing angular stability, located along the external surface, allowed carrying out the stable fixation of both condyles (Fig. 3). Arthroscopically assisted osteosynthesis $(n=15)$ was used in patients with of Schatzker 2 type fracture -4 patients. Arthroscopic

Fig. 2. Reposition of the fracture of the tibia external condyle through the trepanation window
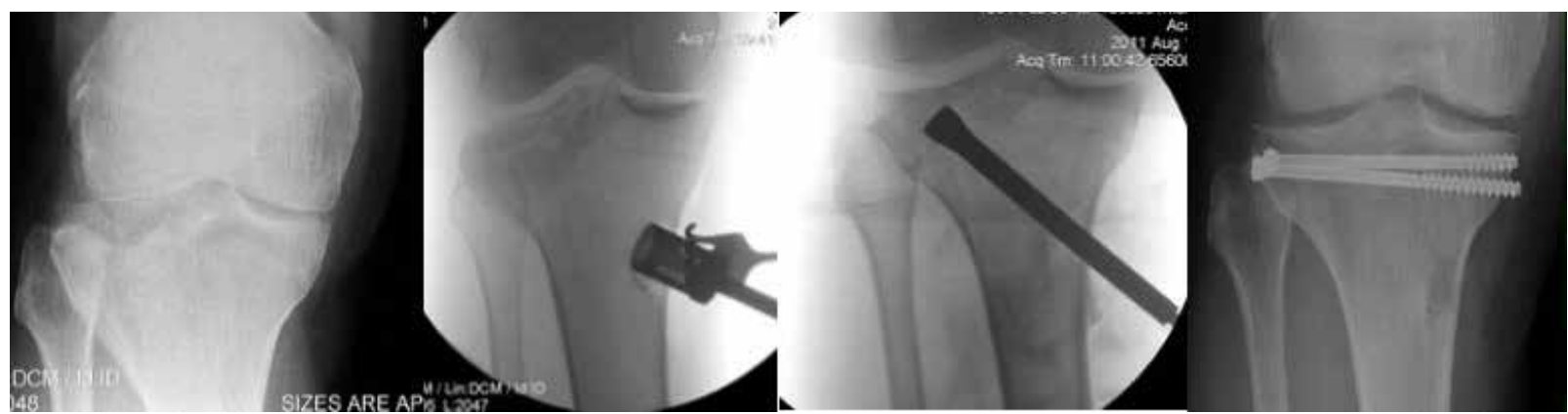


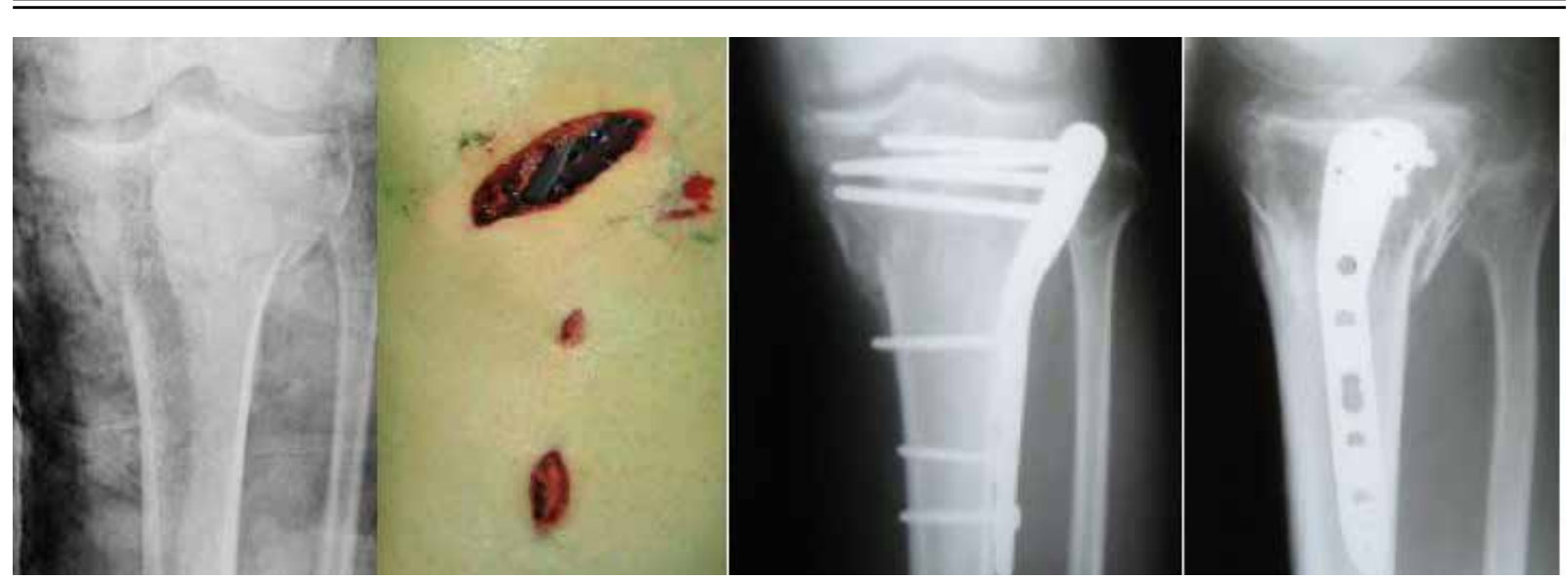

Fig/ 3. Osteosynthesis of Schatzker 5 type fracture with a pre-modulated plate with locking screws

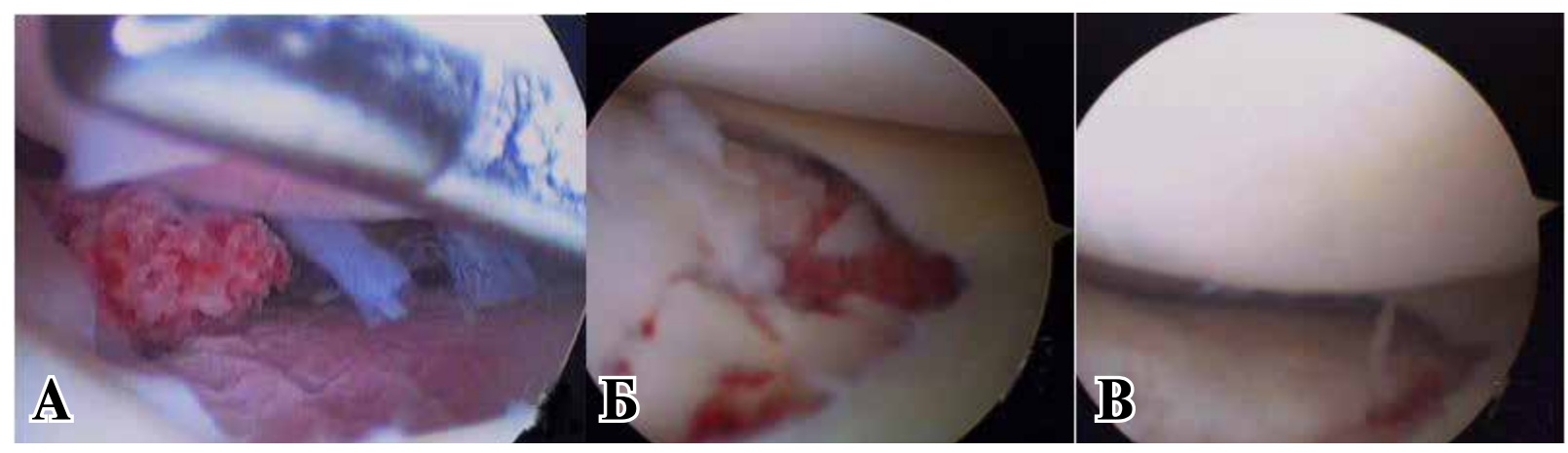

Fig. 4. Arthroscopy in Schatzker type 2 fracture: A - visualization of free bone-cartilaginous bodies, B - type of fracture before repositioning, $B$ - after repositioning

surgery is an additional procedure that allows surgeons to visualize, diagnose, improve treatment of concomitant intraarticular damages and evaluate the reposition of the fracture from the articular surface (Figure 4).

Arthroscopy was performed from the standard anterior external and anterior interior portals. For good visualization, hemarthrosis was washed and small bone-cartilaginous bodies were removed. A pre-made incision in the metaphyseal zone (fracture zone) provided an additional fluid outflow to reduce the risk of developing the compartment syndrome.

Treatment of accompanying damages was performed during the primary operation. There were no meniscus ruptures in the "red" zone, so in injury the operation of choice was partial resection (4 cases). Transosseous injuries of the anterior and posterior cruciate ligaments were diagnosed in 3 cases ( 1 and 2, respectively), and were fixed with the cannulated screws (Figure 5). Osteosynthesis of these injuries in the remote terms would require an extended surgical procedure, since the unreponated intraarticular bone fragments and the maternal bone bed are strongly altered, which makes anatomical reduction impossible. The ruptures of the cruciate ligament injury itself did not occur.

Postoperative treatment. To reduce the edema of the operated limb and prevent vascular disorders, a leg should be in an elevated position. On the second day after the removal of the drainage, fixation of the injured limb in the hinge orthosis was made

Fig. 5. Osteosynthesis of the transosseous injuries of cruciate ligaments: A - forward, $B$ - posterior

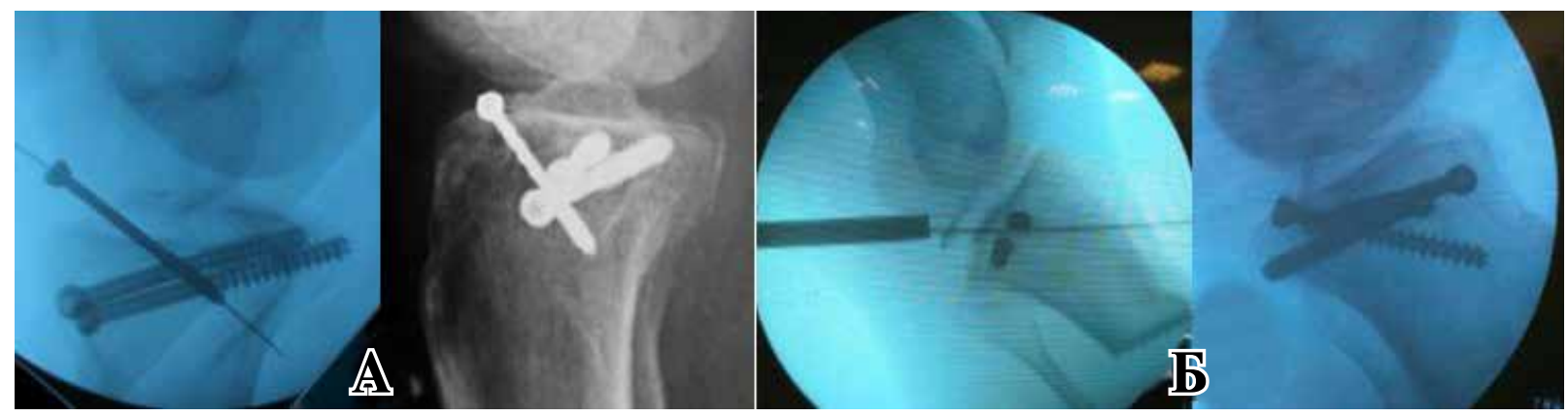


Indices of the hospitalization period in the group Me (25\%-75\%)

\begin{tabular}{lccc}
\hline Type of surgery(number of patients) & $\begin{array}{c}\text { Duration of the } \\
\text { operation, min }\end{array}$ & $\begin{array}{c}\text { Terms of } \\
\text { hospitalization, days }\end{array}$ & $\begin{array}{c}\text { Preoperative } \\
\text { period, days }\end{array}$ \\
\hline Closed reposition, percutaneous fixation with screws $(\mathrm{n}=8)$ & $45(42,5-52,5)$ & $15(9-17,5)$ & $8,5(6-12,5)$ \\
Repositioning through the trepanation window $(\mathrm{n}=12)$ & $60(42,5-65)$ & $13(9,5-19,5)$ & $6(4-11)$ \\
Minimally invasive osteosynthesis with plates $(\mathrm{n}=35)$ & $87,5(60-112,5)$ & $19(14-21,5)$ & $6(4,5-9)$ \\
Arthroscopically assisted osteosynthesis $(\mathrm{n}=15)$ & $75(65-90)$ & $16(11-20)$ & $6(4-8)$ \\
\hline
\end{tabular}

and walking without load on the operated limb by means of crutches was prescribed.

At the same time, physiotherapy and exercise therapy course were prescribed using a continuous passive motion devices. In case of the of Schatzker 1-4 types fractures, the dosed load (50\% of the body weight) was started in 8-12 weeks, with bone fusion in the subchondral and metaphyseal zones on the control radiographs. The full weight load was authorized after 12-14 weeks. In patients with Schatzker 5, 6 types fractures, the recovery time was 2-3 weeks longer. Fixation of the limb with the hinged orthosis had been performed until the fracture was completely fused.

The length of the surgical intervention, the quality of reposition, postoperative complications, the average length of stay in the hospital, functional results, work temporary incapacity were assessed to analyze the results of minimally invasive surgical treatment of fractures of the tibia condyles.

Control studies of patients in the long-term postoperative period were performed 6 weeks, 3 months, 6 months and 1 year later after the operation.

Examination of the knee revealed a soft tissue swelling of the joint, presence or absence of deformation and signs of inflammation, presence of soreness with axial load were noted. Palpation revealed pain in the operation area/ knee joint. The volume of movements in the knee joint (restriction of active and passive movements), axial deviations (varus/valgus) were determined. To assess the clinical outcome of the treatment, the scale of developed in RSPC TO was used. Along with this scale of the RSPC TO, the functional scale for the lower limb, LEFS (Lower extremity functional score) was used to assess adaptation to everyday loads.

The consistency of osteosynthesis (presence/ absence of migration of metal structures, bone resorption); the degree of the fracture fusion; presence of secondary fragment displacement, and axial deviations were determined according X-ray image in the long-term period. Radiography was performed $6,12,25$ weeks and a year later after the operation.

The nonparametric methods were used for statistical analysis of the obtained data, since the distributions of quantitative indicators in the groups differed from normal ones. To describe the distribu- tion in the group, the static Me indices (25\%-75\%) were used. The reliability of the intergroup differences of numerical indices in independent groups was studied using the Mann-Whitney test. For all calculations and comparisons, the results were considered to be statistically significant in reaching of significance level ( $\mathrm{p}$-level) $\mathrm{p}<0,05$.

\section{Results}

Data characterizing the hospitalizatior period in the study group of patients are shown in Table 2.

In general, the results of the study group of patients (group 1, n=70) treated with the use of minimally invasive methods were compared with the results of a similar group of patients (group 2, $n=70$ ) treated with conventional open methods of osteosynthesis:

- the average duration of surgical intervention was 70 (60-90) minutes in group 1 and 100 (90-120) minutes in group $2(\mathrm{p}<0,001)$;

- the average length of stay in the hospital after surgery was 10 (6-13) days in group 1 and 12,5 (9-5) days in group $2(\mathrm{p}<0,001)$;

- the length of stay of a patient in the hospital (bed-days) was 16,5 (12-21) days in group 1 and 19,5 (15-24) days in group $2(\mathrm{p}<0,001)$. A secondary displacement of the joint surface fragments in the early (up to 3 months) incisional period in the group of minimally invasive osteosynthesis was detected in one patient. A retrospective analysis showed the expediency of performing bone plasty in this case.

The long-term X-ray results of treatment showed that both methods of treatment allow achieving a satisfactory repositioning of bone fragments. The advantages of minimally invasive methods of treatment are revealed in the Schatzker 1 and 2 types fractures. The quality of repositioning of Schatzker type 3-6 fractures in both groups is comparable. It should be noted that irrespective of the treatment method applied, the repositioning of bicondylar fractures (Schatzker 5,6) was accompanied by a worse radiographic result compared to the results of single condyle injuries. The frequency of infectious complications in the fractures of the tibia condyles is difficult to analyze in view of the small number of cases. However, there was a statistically 
unreliable difference in the number of infectious complications, $3(4,3 \%)$ in group 1 and $1(1,4 \%)$ in group $2(p=0,62)$. Violation of consolidation and fractures of clamps was not registered.

The average number of points on the scale develooed in the RSPC TO in group 1 was 94 (86-98) and in group 2 it was $89(80-92)(\mathrm{p}<0,001)$. The distribution of the functional results of the surgical treatment of the fractures of the tibia condyles in the long-term period according to the LEFS scale made up 60 (53-68) in group 1 and 53,5 (47-58) in group $2(\mathrm{p}<0,001)$.

After surgical treatment of fractures of the tibia condyles, the average period of patient's work incapacity was $21(17-33,5)$ in group 1 and $24(22-41)$ weeks in group $2(\mathrm{p}<0,001)$

\section{Discussion}

According to the majority of authors, the main way to treat fractures of tibia condyles is considered to be a surgical one, allowing early activation of patients [8]. The development of additional visualization tools has made it possible to introduce widely minimally invasive osteosynthesis technologies in practice. Thus, the use of arthroscopy allows performing a revision of the joint cavity without cutting the meniscus and collateral ligaments, minimizing the injury of soft tissues within the operation. T. Ohdera et al. notes a lower incidence of infectious complications and thrombosis of the deep veins of the lower leg and thigh [9].

The disadvantages of arthroscopic treatment are following: the presence of a large number of equipment in the operating room; difficulty in visualizing part of the tibial plateau located under the meniscus and the risk of developing a compartment syndrome associated with the flow of the fluid from the knee joint cavity into the soft tissues of the lower leg through the fracture line. H. Kiefer and $\mathrm{N}$. Zivaljevic note the success of arthroscopy in the treatment of high-energy fractures - Schaztker 5, 6 [10],however, the complexity of its implementation and the high risk of complications limit the use of this technique.

S. Mardian et al. [11] also points out the prospects of using anatomically pre-cuffed clamps with locking screws provided angular stability, which in some cases allow performing osteosynthesis only with the location of the clamp along the outer surface of the tibia and refusing from submerged osteosynthesis of the opposite side of the joint.

One of the problems in the osteosynthesis of the impression fractures is the recurrent displacement of the joint surface. The bone autoplasty was used in this case. However, to fill the bone defect after repositioning the fracture of the articular surface in the of Schatzker 2,3 type fractures, the crest of the iliac wing, the femoral condyle [12], allobone, bone cement or degradable synthetic materials with osteoconductive effect [13] can be used. Recent prospective, randomized trials $(\mathrm{n}=119)$ show that in the group of patients in whom calcium sulfate was used to fill the bone cavity, a smaller subsidence of the joint surface was found compared to the group of patients with autobone application [14].

\section{Conclusions}

The application of minimally invasive surgical methods for treating fractures of the tibia condyles reduces the duration of the operation, but does not affect the quality of repositioning, minimizes temporary patient disability and achieves better functional results than conventional open methods of treatment.

\section{ЛИТЕРАТУРА}

1. Gruner A, Hockertz T, Reilmann H. Proximal tibial fractures. Unfallchirurg. 2000 Aug;103(8):668ф-84. [Article in German]

2. Hackl W, Riedl J, Reichkendler M, Benedetto KP, Freund M, Bale R. Preoperative computerized tomography diagnosis of fractures of the tibial plateau. Unfallchirurg. 2001 Jun;104(6):519-23. [Article in German] 3. Gardner MJ, Yacoubian S, Geller D, Suk M, Mintz D, Potter H, et al. The incidence of soft tissue injury in operative tibial plateau fractures: a magnetic resonance imaging analysis of 103 patients. J Orthop Trauma. 2005 Feb;19(2):79-84.

4. De Boeck H, Opdecam P. Posteromedial tibial plateau fractures. Operative treatment by posterior approach. Clin Orthop Relat Res. 1995 Nov;(320):125-28.

5. Lasanianos N, Mouzopoulos G, Garnavos C. The use of freeze-dried cancelous allograft in the management of impacted tibial plateau fractures. Injury. 2008 Oct;39(10):1106-12. doi: 10.1016/j.injury.2008.04.005.

6. Schatzker J, McBroom R, Bruce D. The tibial plateau fracture. The Toronto experience 1968-1975. Clin Orthop Relat Res. 1979 Jan-Feb;(138):94-104.

7. Бондарев ОН, Ситник АА. Способ фиксации костных отломков при остеосинтезе перелома наружного мыщелка большеберцовой кости. Патент Респ Беларусь № 18055. 28.02.2014.

8. Chang SM, Hu SJ, Zhang YQ, Yao MW, Ma $Z$, Wang $X$, et al. A surgical protocol for bicondylar four-quadrant tibial plateau fractures. Int Orthop. 2014 Dec;38(12):2559-64. doi: 10.1007/s00264-014-2487-7.

9. Ohdera T, Tokunaga M, Hiroshima S, Yoshimoto E, Tokunaga J, Kobayashi A. Arthroscopic management of tibial plateau fractures-comparison with open reduction method. Arch Orthop Trauma Surg. 2003 Nov;123(9):489-93.

10. Kiefer H, Zivaljevic N, Imbriglia JE. Arthroscopic reduction and internal fixation (ARIF) of lateral tibial plateau fractures. Knee Surg Sports Traumatol Arthrosc. 2001 May;9(3):167-72.

11. Mдrdian S, Landmann F, Wichlas F, Haas NP, Schaser KD, Schwabe P. Outcome of angular stable locking plate fixation of tibial plateau fractures Midterm results in 101 patients. Indian J Orthop. 2015 Nov- 
Dec;49(6):620-29. doi: 10.4103/0019-5413.168755. 12. Sferopoulos NK. Autograft transfer from the ipsilateral femoral condyle in depressed tibial plateau fractures. Open Orthop J. 2014 Sep 30;8:310-15. doi: 10.2174/1874325001408010310. eCollection 2014.

13. Keating JF, Hajducka CL, Harper J. Minimal internal fixation and calcium-phosphate cement in the treatment of fractures of the tibial plateau. A pilot study. J Bone Joint Surg Br. 2003 Jan;85(1):68-73.

14. Russell TA, Leighton RK. Comparison of autogenous bone graft and endothermic calcium phosphate cement for defect augmentation in tibial plateau fractures. A multicenter, prospective, randomized study. J Bone Joint Surg Am. 2008 Oct;90(10):2057-61. doi: 10.2106/JBJS.G.01191.

\section{REFERENCES}

Gruner A, Hockertz T, Reilmann H. Proximal tibial fractures. Unfallchirurg. 2000 Aug;103(8):668-84. [Article in German]

2. Hackl W, Riedl J, Reichkendler M, Benedetto KP, Freund M, Bale R. Preoperative computerized tomography diagnosis of fractures of the tibial plateau. Unfallchirurg. 2001 Jun;104(6):519-23. [Article in German] 3. Gardner MJ, Yacoubian S, Geller D, Suk M, Mintz D, Potter $\mathrm{H}$, et al. The incidence of soft tissue injury in operative tibial plateau fractures: a magnetic resonance imaging analysis of 103 patients. J Orthop Trauma. 2005 Feb;19(2):79-84

4. De Boeck H, Opdecam P. Posteromedial tibial plateau fractures. Operative treatment by posterior approach. Clin Orthop Relat Res. 1995 Nov;(320):125-28. 5. Lasanianos N, Mouzopoulos G, Garnavos C. The use of freeze-dried cancelous allograft in the management of impacted tibial plateau fractures. Injury. 2008 Oct;39(10):1106-12. doi: 10.1016/j.injury.2008.04.005. 6. Schatzker J, McBroom R, Bruce D. The tibial plateau fracture. The Toronto experience 1968-1975. Clin

\section{Адрес для корреспонденции}

220004, Республика Беларусь,

г. Минск, ул. Кижеватова, д. 60/4,

ГУ «Республиканский научно-практический

центр травматологии и ортопедии»,

лаборатория травматологии взрослого возраста, тел. моб.: +375 29 613-18-08,

e-mail: zayonts@mail.ru,

Бондарев Олег Николаевич

\section{Сведения об авторах}

Бондарев О.Н., научный сотрудник лаборатории травматологии взрослого возраста ГУ «Республиканский научно-практический центр травматологии и ортопедии».

\section{Информация о статье}

Поступила 2016 г.

Принята в печать 20 марта 2017 г.

Доступна на сайте 4 мая 2017 г.
Orthop Relat Res. 1979 Jan-Feb;(138):94-104.

7. Bondarev O.N., Sitnik A.A. Sposob fiksatsii kostnykh otlomkov pri osteosinteze pereloma naruzhnogo myshchelka bol'shebertsovoi kosti [The method of fixing bone fragments during osteosynthesis of the fracture of the external condyle of the tibia]. Patent Resp Belarus' №18055. 28.02.2014.

8. Chang SM, Hu SJ, Zhang YQ, Yao MW, Ma $Z$, Wang $X$, et al. A surgical protocol for bicondylar four-quadrant tibial plateau fractures. Int Orthop. 2014 Dec;38(12):2559-64. doi: 10.1007/s00264-014-2487-7.

9. Ohdera T, Tokunaga M, Hiroshima S, Yoshimoto E, Tokunaga J, Kobayashi A. Arthroscopic management of tibial plateau fractures-comparison with open reduction method. Arch Orthop Trauma Surg. 2003 Nov;123(9):489-93.

10. Kiefer H, Zivaljevic N, Imbriglia JE. Arthroscopic reduction and internal fixation (ARIF) of lateral tibial plateau fractures. Knee Surg Sports Traumatol Arthrosc. 2001 May;9(3):167-72.

11. Mдrdian S, Landmann F, Wichlas F, Haas NP, Schaser KD, Schwabe P. Outcome of angular stable locking plate fixation of tibial plateau fractures Midterm results in 101 patients. Indian J Orthop. 2015 NovDec;49(6):620-29. doi: 10.4103/0019-5413.168755.

12. Sferopoulos NK. Autograft transfer from the ipsilateral femoral condyle in depressed tibial plateau fractures. Open Orthop J. 2014 Sep 30;8:310-15. doi: 10.2174/1874325001408010310. eCollection 2014.

13. Keating JF, Hajducka CL, Harper J. Minimal internal fixation and calcium-phosphate cement in the treatment of fractures of the tibial plateau. A pilot study. J Bone Joint Surg Br. 2003 Jan;85(1):68-73.

14. Russell TA, Leighton RK. Comparison of autogenous bone graft and endothermic calcium phosphate cement for defect augmentation in tibial plateau fractures. A multicenter, prospective, randomized study. J Bone Joint Surg Am. 2008 Oct;90(10):2057-61. doi: 10.2106/JBJS.G.01191.

\section{Address for correspondence}

220004, Republic of Belarus,

Minsk, Kizhevatov str., 60/4,

State Institution «Republican Scientific

and Practical Center of Traumatology and Orthopedics», Laboratory of Adult Traumatology

Tel.: 37529 613-18-08,

E-mail: zayonts@mail.ru,

Oleg N. Bondarev

\section{Information about the authors}

Bondarev O.N. researcher of laboratory for traumatology SE "Republican Scientific-Practical Center for Traumatology and Orthopedics", Minsk

\section{Article history}

Recieved 2016

Accepted 20 March 2017

Available online 4 May 2017 